\title{
Cikkismertetés: Alkoholfogyasztás és az általa okozott betegségteher a világ 195 országában és különböző régióiban 1990 és 2016 között: szisztematikus elemzés a 2016-os Globális Betegségteher Vizsgálathoz
}

\author{
Article review: Alcohol use and burden for 195 countries and territories, \\ 1990-2016: a systematic analysis for the Global Burden of Disease Study 2016
}

Ismertetők: $\quad$ Pál László $凹$, Szúcs Sándor

Debreceni Egyetem Népegészségügyi Kar Megelőző Orvostani Intézet

Ismertetett cikk: GBD 2016 Alcohol Collaborators. Alcohol use and burden for 195 countries and territories, 1990-2016: a systematic analysis for the Global Burden of Disease Study 2016. Lancet. 2018 Sep 22;392(10152):1015-1035. doi: 10.1016/S0140-6736(18)31310-2.

Beküldve: $\quad$ 2018. 12. 19.

doi: $\quad$ 10.24365/ef.v60i1.388

Kulcsszavak: alkoholfogyasztás; globális betegségteher; egészségkockázat

Keywords: alcohol consumption; global disease burden; health risk

\section{A TANULMÁNY CÉLA}

Az alkoholfogyasztás összetett hatással van egészségünkre. Epidemiológiai vizsgálatok alapján a túlzott szeszesital-fogyasztás 60 akut és krónikus megbetegedés kockázati tényezője. Ugyanakkor több tanulmány szerint a mérsékelt alkoholbevitel csökkentheti az iszkémiás szívbetegség, és a diabétesz kialakulásának esélyét. Egyes közelmúltban végzett kutatások azonban megkérdőjelezik az alkoholfogyasztás egészségre gyakorolt pozitiv hatásait. Eredményeik alapján a korábban végzett vizsgálatok gyakran zavaró tényezővel terheltek, mint például túlélési torzítás, vagy a nem regisztrált alkoholfogyasztás hatásának figyelmen kívül hagyása. Szintén nehezíti a szeszesital-fogyasztással járó egészségkockázatok pontos meghatározását az, hogy az elfogyasztott alkohol mennyiségétől és fogyasztási gyakoriságától függően az etanol eltérően befolyásolja az egyes szervek, szervrendszerek múködését. Számos korábbi kutatás tett már kísérletet az alkoholfogyasztással járó kockázatok és betegségteher meghatározására, azonban az ezeknél alkalmazott módszertan csak korlátozott becslésekre volt alkalmas. Ezért a szemlében bemutatott kutatás célja, hogy a korábbi eredményekre alapozva az eddiginél jobb becslést nyújtson az alkoholbevitellel összefüggő betegségteherről a világ 195 országában, a 15-95 éves férfi és női korosztályra, 1990 és 2016 között.

\section{MÓDSZER}

A szerzők az eddigiektől eltérő, új módszerek alkalmazásával több zavaró tényező hatását is figyelembe veszik elemzésükben, hogy pontosabb képet adjanak az alkoholfogyasztás által okozott betegségteherről. A kutatásban feldolgozott adatok globálisan, valamint az egyes országok szociodemográfiai indexe (SZDI - magas SZDI, átlag feletti SZDI, átlagos SZDI, átlag alatti SZDI, alacsony SZDI) szerint kerülnek bemutatásra. A SZDI egy ország fejlettségét jellemző mutató, ami magába foglalja az oktatás hozzáférhetőségét, a fertilitást, és az egy főre jutó jövedelmet. 


\section{EREDMÉNYEK}

Globális és regionális alkoholfogyasztás

A világ lakosságának 32,5\%-a (2,4 milliárd fő) fogyasztott rendszeresen szeszesitalt 2016-ban. $\mathrm{Az}$ alkoholfogyasztás nemenkénti prevalenciája nőknél 25\% (0,9 milliárd fő), míg férfiaknál 39\% (1,5 milliárd fő) volt. A naponta elfogyasztott standard szeszesitalok (1 standard szeszesital $10 \mathrm{~g}$ etanolt tartalmaz) mennyisége azonban régiónként és nemenként jelentősen eltért. A magas SZDI-vel rendelkező országokban a naponta megivott standard italok átlagos száma nőknél 1,9, míg férfiaknál 2,9 volt. Az alacsony SZDI kategóriába sorolt államokban alacsony volt az elfogyasztott szeszesitalok átlagos mennyisége nőknél (0,3 ital/nap) és férfiaknál (1,4 ital/nap) egyaránt.

Az alkoholfogyasztással összefüggő halálozás és betegségteher

A tanulmányban bemutatott eredmények szerint 2016-ban világszerte 2,8 millió haláleset állt összefüggésben az alkoholfogyasztással. Ez nőknél a korra standardizált halálozás 2,2\%-a, illetve férfiaknál a 6,8\%-a. A szeszesitalok fogyasztásával kapcsolatos egészségkárosodással korrigált életévek a teljes globális betegségteherhez nőknél 1,6\%-kal, míg férfiakkal 6,0\%-kal járultak hozzá. A korai halálozás és rokkantság rizikótényezői közül az alkoholfogyasztás világszinten a hetedik volt 2016-ban. Ezzel szemben a 15-49 éves korcsoportban már az alkoholfogyasztás volt a vezető kockázati tényező, nőknél a teljes betegségteher 2,3\%-áért, férfiaknál 8,9\%-áért volt felelős. A 15-49 éves korosztályban a nőknél bekövetkezett halálozások 3,8\%-a, míg férfiaknál 12,2\%-a állt összefüggésben a szeszesitalfogyasztással. A vezető halálokok ebben a korcsoportban a tuberkulózis $(1,4 \%)$, a közlekedési balesetek (1,2\%), és az önsértés $(1,1 \%)$ voltak.

\section{Alkoholfogyasztással kapcsolatos egészségkockázat}

Az elemzett adatok alapján a szerzők szignifikáns J-alakú összefüggést találtak az alkoholbevitel és az iszkémiás szívbetegség kialakulásának kockázata között. Ebben az esetben a legalacsonyabb relatív kockázat (RK) férfiaknál 0,83 (RK: 0,86), nőknél 0,92 (RK: 0,82) standard szeszesital elfogyasztását követően fordult elő. Minden más vizsgált kimenetel esetében, ideértve a daganatos megbetegedéseket is, az RK a naponta elfogyasztott alkohol mennyiségével lineárisan növekedett. A szerzők a szeszesitalfogyasztás pozitív és negatív hatásainak figyelembe vételével súlyozott RK-t számítottak. Ennek alapján megállapították, hogy nulla annak a legkisebb mennyiségú standard szeszesitalnak a száma, amit még az egészségkárosodás veszélye nélkül naponta el lehet fogyasztani.

\section{KÖVETKEZTETÉS}

A globális betegségteher egyik legfontosabb rizikótényezője az alkoholfogyasztás, mely a 15-49 éves korosztályban a halálozások közel 10\%-áért felelős. A kutatás eredményei igazolták, hogy nincs biztonságos alkoholfogyasztás. Ezért a szeszesitalfogyasztás csökkentését elősegítő egészségpolitikai intézkedések a leghatékonyabbak az alkohol által okozott betegségteher mérséklésére.

\section{TANULSÁGOK A HAZAI SZAKEMBEREK SZÁMÁRA}

A Globális Betegségteher Vizsgálat alapján nincs biztonságos alkoholfogyasztás. A mérsékelt alkoholbevitel egészségre gyakorolt pozitív hatásai elhanyagolhatók az azzal összefüggő betegségteherrel szemben. Ezek alapján azokat a népegészségügyi intézkedéseket kell előnyben részesíteni, melyek célja az elfogyasztott alkohol mennyiségének csökkentése. 